\title{
Hubungan Hukum Klausula Arbitrase Dengan Yurisdiksi Pengadilan Negeri
}

\author{
Jeffry Latumahina \\ Universitas Bina Sarana Informatika, jeffry.jlm@bsi.ac.id
}

\begin{abstract}
ABSTRAK
Penelitian ini menelaah suatu perjanjian yang mencantumkan klausula arbitrase, yaitu Perjanjian Distribusi antara PT Roche Indonesia ("Roche") dan PT Perusahaan Dagang Tempo ('Tempo") serta Putusan Pengadilan Negeri Jakarta Selatan dalam perkara Roche-Tempo berupa Putusan No.454/Pdt.G/1999/PN.Jak.Sel tanggal 29 Mei 2000. Dalam rangka pendistribusian produk obat-obatan milik Roche di pasar domestik indonesia, Roche mengadakan Perjanjian Distribusi dengan Tempo. Dalam perjalanannya, Roche mengakhiri sebagian Perjanjian Distribusi secara sepihak sehingga Tempo merasakan dirugikan. Tempo mengajukan gugatan atas tindakan Roche tersebut ke Pengadilan Negeri Jakarta Selatan. Gugatan Tempo tersebut dieksepsi oleh Roche. Roche menyatakan bahwa pengadilan negeri tidak berwenang untuk memeriksa dan mengadili perkara gugatan yang diajukan Tempo oleh karena didalam Perjanjian Distribusi dicantumkan klausula arbitrase dimana penyelesaian sengketa seharusnya dilakukan melalui lembaga arbitrase. Penelitian ini bertujuan untuk mengetahui dan menganalisis kekuatan hukum dan eksistensi klausula arbitrase dalam Perjanjian Distribusi ditinjau dari Undangundang No.30 Tahun 1999 tentang Arbitrase dan Alternatif Penyelesaian Sengketa ("UU Arbitrase") selanjutnya juga untuk menganalisa apakah pertimbangan hakim dalam memutuskan sengketa telah sesuai dengan UU Arbitrase. Penelitian ini menggunakan pendekatan yuridis normatif dengan spesifikasi peneletian yang bersifat deskriptif analisis, serta metode analisis data normatif kualitatif. Hasil penelitian menunjukkan bahwa adanya klausula arbitrase dalam Perjanjian Distribusi mempunyai kekuatan hukum mengikat bagi Tempo dan Roche. Pengingkaran terhadap klausula arbitrase oleh Tempo dengan cara mengajukan penyelesaian sengketa kepada pengadilan negeri jelas tidak menghormati kesepakatan yang telah dibuat. Demikian halnya Pengadilan Negeri Jakarta Selatan yang menyatakan bahwa mereka berwenang untuk memeriksa dan mengadili perkara yang terikat klausula arbitrase jelas tidak sesuai dengan UU Arbitrase.
\end{abstract}

Kata Kunci :Klausula Arbitrase; Perjanjian Distribusi; Yurisdiksi Pengadilan; Roche; Tempo

\begin{abstract}
This research analyzed a Distribution Agreement between Roche Indonesia company ("Roche") and distributing company Perusahaan Dagang Tempo ("Tempo") which had an arbitration clause and verdict of South Jakarta District Court in Roche-Tempo case consisted of Putusan No. No.454/Pdt.G/1999/PN.Jak.Sel dated 29 May 2000. In distributing Roche's pharmaceutical products in Indonesian domestic market, Roche had a distribution agreement with Tempo as its sole distributor. During the contract period, Roche terminated part of the contract unilaterally, which suffered Tempo. Tempo then filed a lawsuit against Roche to South Jakarta District Court, which was then rejected by Roche, claiming that the District Court had no jurisdiction over the case since the Distribution Agreement had an arbitration clause stipulating that any dispute must be settled arbitration, not the court.

This Research was aimed to observe and to analyze the legal forces and the existences of arbitration clause in the Distribution Agreement viewed from Law No.30 of 1999 on Arbitration and Alternative Dispute Resolution ("Arbitration Law"). The research was also to find out whether or not the consideration of the Judge in deciding a dispute of an agreement which
\end{abstract}


involves arbitration clause was in accordance with Arbitration Law. This research applies juridical normative approach with the specification of analysis descriptive research, as well as qualitative normative data analysis method. This research showed that the arbitration clause in the Distribution Agreement had a legal force and binding capacity over Tempo and Roche. Tempo's denial of this clause by filing the case to the district court was clearly inappropriate and dishonor the agreement. As for the South Jakarta District Court, which claimed that it had jurisdiction over this case was not in accordance with Arbitration Law.

Keywords: Arbitration Clause; Distribution Agreement; Court Jurisdiction; Roche; Tempo

Naskah diterima: 27-08-2020, direvisi: 25-06-2020, diterbitkan: 01-09-2020

\section{PENDAHULUAN}

Perkampungan global dan ekonomi dalam dunia tanpa batas dengan sendirinya membawa bangsa Indonesia ke kancah business in global village, free market, and free competition. Ini berarti dalam konteks pembangunan nasional, pemerintah Indonesia tidak dapat menampik kenyataan bahwa corak dan konsep dasar pasar bebas dan persaingan bebas dalam segala bentuk harus diterima sebagai kenyataan. Selanjutnya untuk menguatkan hubungan dalam free trade dan free competition, bangsa-bangsa di dunia telah melahirkan international agreement atau persetujuan internasional dalam bentuk perjanjian bilateral atau multilateral. (Yan, 2019)

Sementara untuk perdagangan di dalam negeri sendiri, para pelaku bisnis internasional dapat melakukan transaksi bisnis melalui perjanjian-perjanjian bisnis yang bersifat nasional melalui Perusahaan Modal Asing yang didirikan di Indonesia dan bermitra dengan perusahaan lokal hal mana disebutkan pada (Publication, 2015).

Perkembangan dunia bisnis yang begitu cepat serta kehadiran pelaku bisnis yang memiliki beraneka ragam latar belakang bisnis dalam melakukan kegiatan usahanya baik dalam skala nasional maupun internasional tentunya dapat menimbulkan konflik, oleh karena itu dalam melakukan setiap kegiatan bisnis, para pelaku bisnis tidak dapat melepaskan diri dari suatu perjanjian / kontrak, sebagaimana disebutkan oleh (Subekti \& Tjitrosudibio, 2017) dimana didalam perjanjian / kontrak yang dibuat oleh para pelaku bisnis tersebut harus tersusun secara sistematis mengenai antara lain hak dan kewajiban dari masingmasing pihak; hukum yang akan dipergunakan; forum penyelesaian sengketa; maupun hal-hal lainnya yang berkaitan erat dengan hubungan bisnis yang dijalankan. Hal ini dimaksudkan agar apa yang sudah direncanakan dapat berjalan sesuai dengan apa diharapkan. Namun menurut (Herbots, 2012) dalam praktik ada kalanya hal-hal yang telah disepakati bersama dalam suatu kontrak tidak dapat dilaksanakan oleh karena salah satu pihak mempunyai penafsiran yang berbeda dengan apa yang telah disetujuinya di dalam suatu kontrak bisnis, sehingga hal ini dapat menimbulkan adanya suatu perselisihan. Perselisihan yang timbul jelas tidak menguntungkan para pihak karena perselisihan tersebut dapat menimbulkan suatu sengketa yang merugikan baik dari segi materil maupun immaterial. Perselisihan yang timbul di antara para pihak harus segera diselesaikan, guna untuk menghindari terjadinya sengketa yang lebih besar.

Menurut Komar Kataatmadja dalam (Adolf, 2016), secara garis besar dapat dikatakan bahwa penyelesaian sengketa dapat digolongkan kedalam tiga golongan:

1. Penyelesaian sengketa dengan menggunakan negoisasi, baik berupa negosiasi yang bersifat langsung ( negotiation simpliciter) maupun dengan penyertaan pihak ketiga (mediasi dan konsiliasi);

2. Penyelesaian sengketa dengan cara litigasi, baik yang bersifat nasional maupun internasional; 
3. Penyelesaian sengketa dengan menggunakan arbitrase, baik yang bersifat ad-hoc maupun terlembaga.

Dengan semakin meningkatnya perkembangan perdagangan, keuangan dan industri akhir-akhir ini, apakah nasional maupun internasional akhir-akhir ini, dan ditambah lagi dengan persiapan-persiapan masyarakat internasional menghadapi era globalisasi (Adi Nugroho, 2017) serta meningkatnya kebutuhan dari para pelaku bisnis dalam menyelesaikan sengketasengketa bisnis yang dihadapinya maka, Pemerintah Republik Indonesia dengan sigap telah mengambil inisatif untuk mengeluarkan Undang-Undang No.30 Tahun 1999 tentang Arbitrase dan Alternatif Penyelesaian Sengketa, dimana proses penyelesaian sengketa perdatanya dilakukan melalui sebuah lembaga yang disebut Badan Arbitrase Nasional Indonesia.

Penyelesaian sengketa yang tidak melalui pengadilan disebut sebagai Alternative Dispute Resolution atau Alternatif Penyelesaian Sengketa. Menurut (Bram, 2011) saat ini, cara penyelesaian sengketa alternatif lebih sering mendapatkan perhatian dan digunakan oleh berbagai kalangan, terutama mereka yang berada dalam dunia bisnis, sebagai cara penyelesaian perselisihan yang perlu dikembangkan untuk mengatasi kemacetan penyelesaian melalui pengadilan.

Mantan Ketua BANI (Abdurasyid, 2018) menyatakan bahwa arbitrase dijadikan pilihan penyelesaian sengketa oleh para pengusaha di dalam menyelesaikan sengketa komersialnya, karena ternyata memiliki beberapa kelebihan dan kemudahan, yakni antara lain:

1. Para pihak yang bersengketa dapat memilih para arbitornya sendiri dan untuk ini tentunya akan dipilih mereka yang dipercayai memilik integritas, kejujuran, keahlian dan profesionalisme di bidangnya.

2. Pelaksanaan majelis arbitrase rahasia dan oleh karena itu dapat menjamin rahasia dan publistas yang tidak dikehendaki.

3. Putusan arbitrase sesuai dengan kehendak dan niat para pihak merupakan putusan final dan mengikat para pihak terhadap sengketanya.

4. Karena putusannya final dan mengikat , tata caranya bisa cepat, tidak mahal serta jauh lebih rendah dari biaya-biaya yang harus dikeluarkan dalam proses pengadilan.

5. Tata cara arbitrase lebih informal dari tata cara pengadilan dan oleh karena itu terbuka untuk memperoleh dan tersedianya tata cara penyelesaian kekeluargaan dan damai (amicable).

Selain hal tersebut, menurut (Temitayo Bello, 2019) penyelesaian sengketa melalui arbitrase juga lebih murah serta proses persidangan yang lebih cepat dibandingkan melaui proses litigasi di pengadilan.

Agar suatu sengketa dapat diserahkan pemeriksaannya dan putusannya kepada BANI, maka dalam suatu perjanjian pokok yang dibuat oleh para pihak, harus dicantumkan klausula arbitrase / perjanjian arbitrase. Prinsip yang berlaku umum terhadap perjanjian atau klausula arbitrase adalah berdiri independen dan terlepas sama sekali dari perjanjian pokok. Oleh karena itu, perjanjian arbitrase juga tunduk pada asas-asas dan ketentuan hukum perjanjian yatiu asas kebebasan berkontrak sebagaimana diatur dalam Pasal 1338 KUHPerdata dimana suatu perjanjian berlaku sebagai undang-undang bagi para pihak yang membuatnya.

Dipilihnya lembaga arbitrase sebagai forum penyelesaian sengketa, maka setiap penyelesaian sengketa bisnis yang timbul akibat dari adanya suatu perjanjian / kontrak yang mencantumkan klausula arbitrase adalah bukan kewenangan dari Pengadilan Negeri, hal mana dinyatakan pada Pasal 3 jo Pasal 11 ayat (1) dan ayat (2) UndangUndang No.3 Tahun 1999 yang berbunyi:

1. Pasal 3 berbunyi:

"Pengadilan Negeri tidak berwenang untuk mengadili sengketa para pihak yang telah terikat dalam perjanjian arbitrase".

2. Pasal 11 ayat (1) berbunyi:

"Adanya suatu perjanjian arbitrase tertulis meniadakan hak para pihak untuk mengajukan penyelesaian 
sengketa atau beda pendapat yang termuat dalam perjanjiannya ke Pengadilan Negeri".

3. Pasal 11 ayat (2) berbunyi:

"Pengadilan Negeri wajib menolak dan tidak akan campur tangan di dalam suatu penyelesaian sengketa yang telah ditetapkan melalui arbitrase, kecuali dalam hal-hal tertenu yang ditetapkan oleh undang-undang"

Pasal-pasal tersebut sejalan dengam ketentuan Pasal 1338 KUHPerdata yang berpendirian bahwa setiap perjanjian yang dibuat secara sah berlaku sebagai undangundang bagi mereka yang membuatnya yaitu kesepakatan untuk menyelesaikan semua sengketa atau beda pendapat yang timbul atau yang mungkin timbul dari hubungan hukum tersebut melalui arbitrase dan kesepakatan untuk mengesampingkan yurisdiksi Pengadilan Negeri.

Berdasarkan hal tersebut maka kesepakatan para pihak dalam membuat perjanjian atau kontrak harus dihormati. Keterikatan para pihak pada perjanjian adalah keterikatan kepada isi perjanjian itu. Karena isi perjanjian itu ditentukan oleh para pihak maka mereka sebenarnya terikat kepada janjinya sendiri, janji yang diberikan kepada pihak lain dalam perjanjian. Jadi orang terikat bukan karena ia menghendaki tetapi karena ia memberikan janjinya.Tidak dapat dipungkiri bahwa penyimpangan terhadap klausula arbitrase dapat menjadi salah satu sebab terjadinya permasalahan dalam suatu perjanjian selain permasalahan hukum yang sering ada sebelumnya seperti wanprestasi dan perbuatan melawan hukum.

Apabila dicermati, ternyata perjanjian / kontrak bermasalah dapat terjadi karena adanya ketentuan yang dituangkan dalam sebuah kontrak tidak dilaksanakan atau tidak dapat dilaksanakan, sekalipun seluruh unsurunsur yang disyaratkan bagi sebuah kontrak yang sah telah terpenuhi.

Terhadap perjanjian-perjanjian yang mencantumkan klausula arbitrase terdapat fenomena dimana salah satu pihak tidak memahami makna dicantumkannya klausula arbitrase dalam suatu perjanjian. Hal ini jelas memperlihatkan kurangnya rasa penghormatan terhadap suatu perjanjian yang telah disepakati oleh para pihak.

Seperti misalnya Kasus hukum antara PT Roche Indonesia dan PT Perusahaan Dagang Tempo merupakan kasus yang bermula dari tindakan pengakhiran Perjanjian Distribusi antara Roche dan Tempo yang muncul kepermukaan untuk selanjutnya diproses lebih lanjut melalui jalur hukum.

Kasus hukum yang terjadi antara PT Roche Indonesia melawan PT Perusahaan Dagang Tempo di Pengadilan Negeri Jakarta Selatan, adalah berkaitan dengan pengakhiran perjanjian distribusi obatobatan. Sesuai dengan ketentuan didalam perjanjian distribusi disebutkan bahwa apabila timbul perselisihan atau ketidaksepakatan antara para pihak berkenaan atau berkaitan dengan perjanjian, maka pihak Roche dan Tempo sepakat untuk menyelesaikannya dengan cara musyawarah. Apabila perselisihan tersebut tidak dapat diselesaikan dengan jalan musyawarah, maka para pihak sepakat untuk menyelesaikan sengketa melalui Badan Arbitrase Nasional Indonesia.

Dalam kenyataannya, pada saat timbul sengketa di antara Roche dan Tempo, sengketa tersebut diserahkan ke Pengadilan Negeri Jakarta Selatan untuk diperiksa dan diadili. Pengajuan gugatan yang dilakukan oleh Pihak Tempo ke Pengadilan Negeri, antara lain dengan alasan bahwa, Pertama: pengakhiran sebagian Perjanjian Distribusi tidak dilakukan Roche melalui mekanisme arbitrase, Kedua: Pihak Tempo berkeyakinan bahwa perselisihannya dengan pihak Roche bersifat teknis yuridis tentang perbuatan melawan hukum sedemikian rupa sehingga sengketa tersebut dapat diselesaikan di Pengadilan Negeri Jakarta Selatan. Hal ini yang membuat peneliti tertarik untuk mengetahui dan menganalisis kekuatan hukum dan eksistensi klausula arbitrase (arbitration clause) dalam Perjanjian Distribusi ditinjau dari UndangUndang No.30 Tahun 1999 tentang 
Arbitrase dan Alternatif Penyelesaian Sengketa. Selain itu penulis meneliti apakah pertimbangan hakim Pengadilan Negeri dalam memeriksa dan memutus suatu sengketa yang memuat klausula arbitrase telah sesuai dengan Undang-Undang No.30 Tahun 1999 tentang Arbitrase dan Alternatif Penyelesaian Sengketa.

\section{KAJIAN LITERATUR \\ Sumber Hukum Arbitrase}

Salah satu aspek dalam kehidupan hukum adalah kepastian. Ini berarti bahwa hukum berkehendak menciptakan kepastian dalam mengatur hubungan antar orang-orang dalam masyarakat, dan salah satu hal yang berhubungan erat dengan masalah kepastian hukum ialah masalah darimana hukum itu.

Sebelum membicarakan arbitrase terlebih dahulu akan dibahas mengenai asal mula keberadaan arbitrase dalam tata hukum di Indonesia dengan demikian kita akan akan tahu persis titik tolak pemikiran dalam mengupas arbitrase.

\section{a. Pasal 377 HIR}

Pasal ini menegaskan hal-hal sebagai berikut:(Harahap, 2015)

1) Pihak-pihak yang bersangkutan diperbolehkan menyelesaikan sengketa melalui juru pisah atau arbitrase.

2) Arbitrase diberi dan kewenangan untuk menyelesaikannya dalam bentuk keputusan.

3) Untuk itu, baik para pihak maupun arbiter wajib tunduk menuruti peraturan hukum acara yang berlaku bagi bangsa atau golongan Eropa.

\section{b. Pasal 615-651 Rv}

Dalam buku ketiga Reglement Acara Perdata (Rv) diatur ketentuan mengenai putusan wasit (arbitrase) yang terdiri atas Pasal 615 sampai Pasal 651. Pasalpasal inilah yang wajib dituruti dan diterapkan sebagai landasan hukum umum ke-arbitrasean sejak dulu sampai sekarang.

\section{c. Undang-undang No.30 Tahun 1999}

Dalam penjelesan Pasal 3 ayat (1) Undang-undang No.4 Tahun 2004 tentang kekuasaan kehakiman antara lain disebutkan bahwa penyelesaian perkara diluar pengadilan atas dasar perdamaian atau melalui arbitrase tetap diperbolehkan. Akan tetapi, putusan arbitrase hanya mempunyai kekuatan eksekutorial setelah memperoleh izin atau perintah untuk dieksekusi dari pengadilan.

Pada tanggal 12 Agustus 1999, telah terjadi momentum sejarah dalam bidang Arbitrase di Indonesia dimana Pemerintah Republik Indonesia berdasarkan Lembaran Negara Tahun 1999 No.138 telah mengundangkan berlakunya Undang-undang No.30 Tahun 1999 tentang Arbitrase dan Alternatif Penyelesaian Sengketa.

Dengan disahkannya Undang-Undang No.30 Tahun 1999, maka ketentuan arbitrase yang selama ini diatur dalam Pasal 377 HIR dan Pasal 615 sampai $651 \mathrm{Rv}$, dinyatakan tidak berlaku.

\section{Perjanjian dan Klausula Arbitrase}

Menurut (Friedland \& Nyer, 2014) perjanjian untuk memilih aribtrase dapat dilakukan sebelum maupun setelah terjadinya suatu sengketa. Hal ini sesuai dengan ketentuan Pasal 1 angka ke-3 Undang-Undang No.30 Tahun 1999 yang menyatakan bahwa: " Perjanjian arbitrase itu adalah suatu kesepakatan berupa klausula arbitrase yang tercantum dalam suatu perjanjian tertulis yang dibuat para pihak sebelum timbul sengketa, atau suatu perjanjian arbitrase tersendiri yang dibuat setelah timbul sengketa".

Berdasarkan rumusan undang-undang tersebut, maka arbitrase lahir karena adanya perjanjian yang dibuat secara tertulis oleh para pihak, yang berisikan perjanjian untuk menyelesaikan suatu sengketa di bidang perdata di luar peraadilan umum melalui arbitrase. Perjanjian arbitrase yang lazim disebut "klausula arbitrase" merupakan perjanjian yang berdiri sendiri yang lahir akibat adanya perjanjian pokok.

Dalam praktek dan penulisan, persetujuan arbitrase selalu disebut klausul arbitrase 
(arbitration clause). Penggunaan istilah klausul arbitrase mengadung konotasi bahwa Perjanjian pokok yang bersangkutan diikuti atau dilengkapi dengan persetujuan mengenai pelaksanaan arbitrase.Dengan kata lain, perjanjian pokok yang bersangkutan mengandung klausul arbitrase.

\section{Kekuatan Hukum Klausula Arbitrase Dalam Perjanjian}

Istilah klausula dalam suatu perjajian mengandung konotasi bahwa klausula merupakan suatu bagian dari suatu perjanjian yang memuat ketentuan-ketentuan yang bersifat khusus, demikian pula halnya dengan klausula arbitrase seolah-olah mengadung arti bahwa klausula arbitrase merupakan bagian dari suatu perjanjian yang memuat syarat-syarat dan ketentuanketentuan tentang cara-cara penyelesaian sengketa melalui arbitrase, padahal jika dilihat dari bunyi Pasal 1 Undang-Undang No.30 Tahun 1999 maka bentuk-bentuk perjanjian arbitrase meliputi perjanjian yang dibuat sebelum timbul sengketa dan perjanjian arbitrase tersendiri yang dibuat setelah timbul sengketa

Kesepakatan para pihak untuk membuat perjanjian arbitrase sejalan dengan sistem hukum perjanjian di Indonesia yang diatur dalam KUH Perdata yang menganut sistem terbuka dan mengandung asas kebebasan membuat perjanjian, hal ini dapat disimpulkan dari ketentuan Pasal 1338 ayat (1) KUH Perdata yang menyebutkan "sетиa perjanjian yang dibuat secara sah berlaku sebagai undang-undang bagi mereka yang membuatnya"

Walaupun dalam sistem hukum perjanjian di Indonesia dikenal asas kebebasan berkontrak sebgaimana disimpulkan dalam Pasal 1338 KUHPerdata tetapi agar perjanjian tersebut mempunyao kekuatan mengikat maka, suatu perjanjian harus memenuhi Pasal 1320 ayat (1) KUHPerdata tentang syarat-sayarat sahnya perjanjian.yaitu:

"Untuk sahnya persetujuan-persetujuan diperlukan empat syarat"

1. sepakat mereka yang mengikatkan
dirinya;
2. kecakapan untuk membuat suatu perikatan;

3. suatu hal terntentu;

4. suatu sebab yang halal

Dengan dipenuhinya syarat-syarat tersebut maka perjanjian arbitrase tersebut dari aspek keperdataan mempunyai daya mengikat sebagaimana dimaksud dalam Pasal 1338 ayat (1) KUHPerdata yaitu berlaku sebagai undang-undang bagi mereka yang membuatnya, sehingga para pihak terikat dengan kesepakatan yang telah dibuat secara tertulis yaitu untuk menyelesaikan segala persoalan atau sengketa yang mereka hadapi melalui forum arbitrase, dimana kesepakatan tersebut tidak dapat ditarik kembali secara sepihak sebagaimana diatur dalam Pasal 1338 ayat (2) KUHPerdata, yang menyebutkan " persetujuan-persetujuan itu tidak dapat ditarik kembali selain dengan sepakat kedua belah pihak atau karena alasan-alasan yang oleh undang-undang dinyatakan cukup untuk itu".

Dengan demikian maka kedudukan klausula arbitrase dalam sistem hukum perjanjian di Indonesia sebagaimana diatur dalam Pasal 1338 KUHPerdata adalah bersifat mengikat dan harus ditaati serta dihormati bukan saja oleh para pihak yang membuatnya akan tetap patut pula untuk dihormati oleh institusi peradilan di Indonesia sebagaimana diatur dalam Pasal 3 juncto Pasal 11 ayat (2) Undang-Undang No.30 Tahun 1999.

Makna dari mengikatnya perjanjian arbitrase tersebut dikarenakan pilihan forum arbitrase tersebut didasarkan adanya kehendak para pihak yang membuat perjanjian yang menginginkan penyelesaian sengketanya dilaksanakan melalui forum arbitrase.

Sejak para pihak mengikatkan diri pada perjanjian arbitrase maka sejak saat itu dengan sendirinya telah lahir kompetensi absolute arbitrase untuk menyelesaikan sengketa yang timbul dari suatu perjanjian, oleh karena itu, ada atau tidaknya eksepsi yang diajukan oleh para pihak yang berperkara, pengadilan haruslah tunduk pada ketentuan Pasal 11 ayat (2) Undang-Undang No,30 Tahun 1999 jo Pasal 134 HIR yang menyebutkan : 
1) Pasal 11 ayat (2) Undang-Undang No.30 Tahun 1999 berbunyi:"Pengadilan Negeri wajib menolak dan tidak akan campur tangan didalam suatu penyelesaian sengketa telah ditetapkan melalui arbitrase, kecuali dalam hal-hal tertentu yang diterapkan dalam undang-undang ini"

2) Pasal 134 HIR yang menyebutkan:

"tetapi dalam hal perselisihan itu mengenai suatu perkara yang tiada masuk kekuasaan pengadilan negeri, maka pada sebarang waktu pemeriksaan perkara itu boleh dituntut, supaya hakim mengaku dirinya tidak berhak dan hakim sendiri berwajib mengakui itu karena jabatannya"

\section{METODE PENELITIAN}

Metode pendekatan yang dipergunakan dalam peneletian ini adalah yuridis normatif atau disebut juga dengan penelitian dokumen. Metode ini mempergunakan data sekunder yang berupa hukum positif dan bahan-bahan kepustakaan seperti bukubuku, karya ilmiah, makalah seminar dan dokumen perjanjian distribus antara PT Roche Indonesia ("Roche") dan PT Perusahaan Dagang Tempo ("Tempo"), Putusan Pengadilan Negeri Jakarta Selatan No.454/Pdt.G/1999/PNJakSel tanggal 29 Mei 2000. Metode yuridis normatif ini digunakan untuk memahami kenyataan yang ada dikaitkan dengan peraturan perundangundangan yang ada.

Spesifikasi penelitian yang digunakan adalah deskriptif analitis, yaitu dengan menggambarkan suatu obyek permasalahan yang berupa fakta-fakta dalam lingkup perjanjia. Selanjutnya peraturan perundangundangan yang berlaku terkait dengan obyek permasalahan digunakan untuk menganalisis obyek permasalahan yang diteliti, dihubungkan dengan teori-teori dan asasasas hukum serta praktek-praktek yang terjadi dalam suatu perjanjian yang memuat klausula arbitrase.

Peneltian ini dialkukan dalam dua tahap yang meliputi:

1. Penelitian kepustakaan (library research) yaitu mengumpukan data sekunder yang terdiri dari : a) Bahah-bahan buku primer berupa peraturan perundang-undangan yang berlaku dan terkait, misalnya:

i. Kitab Undang-Undang Hukum Perdata;

ii. Kitab Undang-Undang Hukum Dagang;

iii. Undang-Undang tentang Arbitrase dan Penyelesaian Sengketa;

iv. Undang-Undang Kekuasaan Kehakiman;

v. Undang-Undang Program Pembangunan Nasional;

vi. UNCITRAL Arbitration Rules, 1976

b) Bahan-bahan hukum sekunder berupa bahan-bahan yang erat hubungannya dengan bahan hukum primer dan dapat digunakan untuk menganalisis bahan hukum primer, seperti bukubuku, karya ilmiah, tulisan para ahli hukum dan makalah hasil seminar, Perjanjian Distribusi antara Roche dan Tempo tanggal 9 Desember 1996, Putusan Pengadilan Negeri Jakarta Selatan

No.454/Pdt.G/1999/PNJakSel tanggal 29 Mei 2000.

c) Bahan-bahan hukum tersier berupa majalah, jurnal, surat kabar, kamus hukum, kamus ekonomi serta bahan yang didapat dengan cara mengakses beberapa situs website melalui internet.

2. Penelitian lapangan (field research) yaitu tahap penelitian di lapangan yang dilakukan dalam rangka menunjang data sekunder.

Pengumpulan data penelitian dilakukan dengan teknik sebagai berikut:

1. Studi dokumen yaitu melakukan suatu penelitian terhadap dokumen-dokumen yang erat kaitannya dengan keberadaan klusula arbitrase dalam rangka mendapatkan landasan teoritis dan informasi dalam bentuk kententuan formal serta dalat melalui naskah resmi yang ada.

2. Wawancara atau diskusi, yaitu mengadakan tanya jawab atau disikusi untuk memperoleh data primer secara 
langsung dalam lingkup klausula arbitrase sehubungan dengan pemeriksaan sengketa terhadap perjanjian yang mencantumkan klausula arbitrase.

Kesimpulan yang ditarik dari hasil penelitian telah dilakukan dengan suatu metode analisis normatif kualitatif. Secara normatif karena peraturan perundang-undangan yang berlaku dan terkait sebagai hukum positif yang ada merupakan sumber atau titik tolak dalam penelitian ini, sedangkan secara kualitatif karena informasi-informasi yang didapat melalui wawancara maupun diskusi yang disampaikan oleh pihak responden terkait digunakan untuk memperoleh suatu analisis data tanpa mempergunakan rumus matematika ataupun angka-angka

Dalam melakukan kegiatan perolehan datadata yang diperlukan di Perpustakaan Fakultas Hukum Universitas Padjadjaran di Bandung, Perpustakaan Fakultas Hukum Universitas Indonesia di Jakarta, Perpustakaan Nasional Republik Indonesia di Jakarta serta penelitian pada Pengadilan Negeri Jakarta Selatan.

\section{PEMBAHASAN}

Perkembangan transaksi bisnis didunia saat ini sudah semakin dinamis. Berbicara masalah transaksi bisnis tidak dapat dilepaskan dari keberadaan perjaanjian sebagai wadah untuk menuangkan hal-hal yang merupakan kepentingan dari para pihaknya. Masyarakat sudah semakin menyadari pentingnya suatu pemahaman memuat klausula-klausula yang telah disepakati dan selanjutnya untuk dilaksanakan oleh para pihak.

Klausula arbitrase yang merupakan salah satu unsur pokok dalam suatu perjanjian adalah suatu kesepakatan dari para pelaku bisnis untuk menyelesaikan sengketa yang sudah timbul maupun yang akan timbul diantara mereka melalui forum arbitrase, harus dipahamai secara benar pula agar didalam penerapannya tidak mengalami masalah yang serius.

Sejak tahun 1974, Tempo telah menjadi distributor untuk produk-prodek Roche di pasar Indonesia yang didasarkan pada suatu Perjanjian Distribusi yang telah beberapa kali mengalami perpanjangan hingga perpanjangan terakhir pada tanggal 9 Desember 1996. Dalam Perjanjian Distribusi tersebut Roche mengangkat dan menunjuk Tempo sebgai distributor tunggal untuk pemasaran dan penjualan produk-produk Roche untuk jangka waktu tidak terbatas.

Namun diluar dugaan Tempo, Roche melalui suratnya No.GM/DG/CA/322 tanggal 31 Agustus 1999 menyatakan bahwa terhitung mulai tanggal 29 Pebruari 2000, Roche secara

Sepihak, mengakhiri Perjanjian Distribusi untuk produk-produk divisi Over The Counter (OTC).

Akibat pemutusan perjanjian tersebut oleh Roche, maka Tempo dengan surat gugatanya tertanggal 29 September 1999 dibawah register perkara No.454/Pdt.G/1999/PNJakSel tanggal 29 Mei 2000 mengajukan gugatan perbuatan melawan hukum kepada Roche.

\section{Aspek Yuridis Perjanjian Distribusi PT Roche Indonesia dan PT Perusahaan} Dagang Tempo (Roche \& Tempo, 1996)

Roche adalah suatu perusahaan yang mempunyai kegiatan usaha mengimpor obat-obatan serta melakukan produksi obatobatan di Indonesia seperti Redoxon, Supradyn, Saridon. Roche berkeinginan untuk melakukan pengembangan usaha di Indonesia dengan cara membuka jalur penjualan dan distribusi semua produk Roche di pasar domestik Indonesia baik terhadap obat-obatan yang diproduksi di Indonesia maupun produk obat-obatan yang diimpor oleh Roche.

Tempo adalah suatu badan hukum yang didirikan berdasarkan hukum negara Indonesia dan memilik kemampuan yang baik dibidang penjualan dan pendistribusian barang yang dibutuhkan untuk mendukung pengembangan proyek Roche tersebut.

Untuk mengembangkan usahanya, Roche menawarkan kerjasama dan menunjuk Tempo sebagai wakil dari Roche untuk melakukan pendistribusian obat-obatan di 
pasar domestik Indonesia yang terdiri dari dua divisi yaitu divisi OTC dan RX. Penawaran dari Roche diterima oleh Tempo dan kemudian para pihak sepakat untuk mengadakan suatu kerjasama yang diikat dalam suatu perjanjian yaitu Perjanjian Distribusi.

Perjanjian Distribusi mengatur ketentuan mengenai hak dan kewajiban dari Roche dan Tempo khususnya antara lain mengenai pasokan produk, pengangkutan produk, asuransi, pendistribusian produk dan lainlain. Perjanjian Distribusi juga mengatur tentang pengakhiran perjanjian dimana untuk mengakhiri Perjanjian Distribusi, salah satu pihak harus menyampaikan pemberitahuan tertulis 6 (enam) bulan sebelumnya kepada pihak lainnya.

Hal penting lain yang disepakati oleh Roche dan Tempo di dalam Perjanjian Distribusi adalah ketentuan mengenai cara menyelesaikan sengketa yang timbul diantara mereka berdasarkan Perjanjian Distribusi yang menyebutkan bahwa (Roche \& Tempo, 1996): Apabila timbul perselisihan atau ketidaksepakatan antara para pihak berkenaan atau berkaitan dengan perjanjian, para pihak tersebut sepakat untuk mempertahankan hubungan dengan cara terhormat, itikad baik dan saling mempercayai dan oleh karena itu maka, penyelesaian masalah akan ditempuh melalui musyawarah untuk mufakat, hal mana secara tegas disebutkan dalam Pasal 19.1 Perjanjian Distribusi.

Dalam Pasal 19.2 dikatakan bahwa apabila timbul perselisihan di antara para pihak berkenaan dengan Perjanjian tidak dapat diselesaikan secara musyarawah sebagaimana dimaksud pada Pasal 19.1 maka, perselisihan akan diselesaikan melalui arbitrase. Berikutnya di Pasal 19.3 disebutkan bahwa sementara menunggu penyerahan kepada arbitrase dan setelahnya sampai keputusan final dari para arbiter, para pihak wajib tanpa mengurangi hak masing-masing, untuk terus menghormati kewajiban-kewajiban mereka dan melaksanakan semua tugas mereka sesuai perjanjian.

\section{Analisa Yuridis Terhadap Kekuatan dan Eksistensi Klausula Arbitrase Dalam Penyelesaian Sengketa Perjanjian Distribusi}

Adalah suatu hal yang wajar apabila dalam suatu yang telah disepakati, masih saja terjadi perbedaan pendapat, namun hal tersebut akan menjadi semakin rumit apabila kemudian terjadi ketidaksepahaman menyangkut tempat dimana perselisihan tersebut diselesaiakan.Berdasarkan ketentuan pasal 19.2 Perjanjian Distribusi, telah diatur ketentuan mengenai klausula arbitrase bahwa: (Roche \& Tempo, 1996) "apabila timbul perselisihan di antara para pihak berkenaan atau dalam hubungannya dengan Perjanjian atau pelanggaran yang tidak dapat diselesaikan secara musyawarah, maka akan diselesaikan melaui arbitrase yang dilaksanakan dalam bahasi Inggris dan diselenggarakan di Jakarta berdasarkan aturan-aturan dari Badan Arbitrase Nasional Indonesia ("BANI") untuk menyelesaiakan perselisihan tersebut melalui sebuah majelis yang terdiri atas 3 (tiga) orang yang ditunjuk".

Namun pada saat timbul sengketa, Tempo malah menyerahkan penyelesaian sengketa yang timbul tersebut ke Pengadilan Negeri dengan alasan bahwa perselisihan yang penyelesaiannya dengan cara arbitrase adalah apabila perselisihan tersebut sifatnya teknis dibidang bisnis yang pada umumnya dipahami oleh para arbiter. Menurut Tempo, sengketa yang timbul di antara Roche dan Tempo sama sekali bukanlah teknis dalam bidang bisnis, karena masalahnya adalah mengenai tindakan Roche yang secara sepihak memutuskan Perjanjian Distribusi. Masalah pemutusan Perjanjian Distribusi adalah murni teknis yuridis dan bukan teknis di bidang bisnis dan karenanya, hakim pengadilan negeri yang mempunyai kewenangan (kompetensi) untuk memeriksa perkara.

Dengan mengacu pada ketentuan Pasal 19 Perjanjian Distribusi, Roche kemudian mengajukan eksepsi, dan menyatakan bahwa Pengadilan Negeri Jakarta Selatan tidak berwenang untuk memeriksa dan mengadili 
perkara. Pengadilan Negeri Jakarta Selatan dalam putusan sela dan tingkat pertama menolak eksepsi tersebut dan tetap menyatakan bahwa : (PNJaksel, 2000)

Pengadilan Negeri Jakarta Selatan berwenang / kompeten untuk memeriksa dan mengadili perkara antara lain dengan alasan bahwa pokok permasalahan sengketa antara Roche dan Tempo bukanlah berkenaan dengan persengketaan tentang pelaksanaan perjanjian yang harus diselesaikan melalui Badan Arbitrase Nasional Indonesia, melainkan sengketa tentang perbuatan melawan hukum di dalam pemutusan secara sepihak atas ketentuan yang telah disepakati dalam Perjanjian Distribusi tersebut.

Sengketa yang demikian menurut hemat majelis hakim sama sekali tidak membutuhkan penyelesain melalui arbiter yang dipandang harus lebih mampu dan menguasai permasalahan teknis bisnis yang disengketakan, melainkan dibutuhkan penyelesaian secara hukum dihadapan pengadilan. Melalui pertimbangan tersebut maka menurut Majelis: persengketaan antara Roche dan Tempo sama sekali bukan merupakan kewenangan arbitrase melainkan kewenangan pengadilan. (PNJaksel, 2000)

Berdasarkan uraian yang penulis sampaikan pada bagian pembahasan, dapat dilihat bahwa, terdapat pengaruh yang kurang baik dalam praktik bisnis jika pihak-pihak yang terlibat dalam penyelesaian suatu sengketa perjanjian yang mencantumkan klausula arbitrase tidak memahami dengan baik atau tidak menghormati janji yang telah disepakatinya dalam suatu perjanjian / kontrak tersebut.

Klausula arbitrase yang tercantum dalam Perjanjian Distribusi tidak hanya nengikat kepada para pihak yang membuat perjanjian namun juga mengikat institusi peradilan umum, hal ini sejalan dengan Pasal 3 junto Pasal 11 ayat (2) Undang-Undang No.30 Tahun 1999. Dengan keberadaan klausula arbitrase pada Pasal 19 Perjanjian Distribusi tersebut maka, penyelesaian perselisihan atau sengketa melalui pranata arbitrase bersifat absolut terhadap penyelesaian perselisihan atau sengketa melalui peradilan.
Dengan kata lain bahwa suatu perjanjian atau klausula arbitrase yang telah disepakati oleh para pihak akan menghapuskan kewenangan lembaga Pengadilan Negeri untuk menyelesaikan setiap perselisihan atau sengketa yang timbul dari perjanjian yang memuat klausula arbitrase.

\section{PENUTUP}

Berdasarkan analisis dan pembahasan di bab-bab sebelumnya maka dapat disimpulkan: Adanya klausula arbitrase dalam ketentuan Pasal 19 Perjanjian Distribusi mempunyai kekuatan hukum yang mengikat bagi Roche dan Tempo, Institusi Peradilan Umum serta Badan Arbitrase Nasional Indonesia sebagaimana dimaksud dalam klausula arbitrase tersebut.

Putusan Pengadilan Negeri Jakarta Selatan terhadap sengketa Roche dan Tempo yang menyatakan bahwa Pengadilan Negeri Jakarta Selatan berwenang untuk memeriksa dan mengadili perkara yang terikat dengan klausula arbitrase, tidak sesuai dengan Undang-Undang No.30 Tahun 1999 tentang Arbitrase dan Alternatif Penyelesaian Sengketa.

Untuk peneltian selanjutnya dapat dikembangkan dengan meneliti lebih lanjut masalah masih terbukanya peluang bagi pihak yang beritikad tidak baik untuk memanfaatkan upaya hukum Banding, Kasasi dan Peninjauan Kembali khususnya bagi suatu putusan Pengadilan Negeri yang menyatakan bahwa Pengadilan Negeri tidak berwenang untuk memeriksa dan mengadili perkara-perkara perdata yang terikat dengan perjanjian atau klausula arbitrase, hal ini semata-mata untuk mendukung tujuan penyelesaian sengketa melalui arbitrase.

\section{REFERENSI}

Abdurasyid, P. (2018). Arbitrase dan Alternatif Penyelesaian Sengketa Suatu Pengantar. Fikahati Aneka.

Adi Nugroho, S. (2017). Penyelesaiaan Sengketa Arbitrase dan Penerapan Hukumnya. Prenada Media. 
Adolf, H. (2016). Arbitrase Komersial Internasional (Edisi Revisi) (Revisi). Keni Media.

Bram, D. Al. (2011). Penyelesaian Sengketa Bisnis Melalui Mediasi (E. Wijaya \& D. Bram (eds.); 1st ed.). Pusat Kajian Ilmu Hukum Universitas Pancasila.

Friedland, P., \& Nyer, D. (2014). Soft Law in International Arbitration (L. W. Neyman \& M. J. Radine (eds.)). JurisNet, LLC.

Harahap, Y. (2015). arbitrase (2nd ed.). Sinar Grafika.

Herbots, J. H. (2012). Interpretation of Contracts (J. M. Smits (ed.)). Edward Elgar.

PNJaksel. (2000). Putusan Perkara Perdata No.454/Pdt.G/1999/PNJakSel tanggal 29 Mei 2000, antara PT PT Roche Indonesia dan PT Perusahaan Dagang Tempo.

Publication, I. B. (2015). Indonesia: Mineral, Mining Sector Investment and Business Guide (1st ed.). Global Investment Center, USA.

Roche, \& Tempo. (1996). Distribution Agreement between PT Roche Indonesia and PT Tempo.

Subekti, R., \& Tjitrosudibio, R. (2017). Kitab Undang-Undang Hukum Perdata (Cetakan Ma). Pradnya Paramita.

Temitayo Bello. (2019). Why Arbitration Triumphs Litigation. SSRN, 10. https://papers.ssrn.com/sol3/papers.cf m?abstract_id=3354674

Yan, H. (2019). The China-Australia Free Trade Agreement and the Choice of Interest Balance in the Two Countries (L. Corby \& M. Perry (eds.)). Springer. https://doi.org/https//:doi.org/10.1007/ 